\title{
Improving neurologic and quality-of-life outcomes in children with congenital heart disease: Past, present, and future
}

\author{
Gil Wernovsky, MD
}

See related articles on pages 347 and 355.

Supplemental material is available online.
From the Cardiac Intensive Care Unit, The Cardiac Center at The Children's Hospital of Philadelphia, and the University of Pennsylvania School of Medicine, Philadelphia, Pa.

Received for publication April 6, 2007; revisions received June 26, 2007; accepted for publication July 5, 2007.

Address for reprints: Gil Wernovsky, MD, Pediatric Cardiology, 34th St and Civic Center Blvd, Philadelphia PA, 19104 (E-mail: Wernovsky@email.chop. edu).

J Thorac Cardiovasc Surg 2008;135:240-2

$0022-5223 / \$ 34.00$

Copyright () 2008 by The American Association for Thoracic Surgery

doi:10.1016/j.jtcvs.2007.07.057
They say that time changes things, but you actually have to change them yourself (Andy Warhol).

\section{Prostaglandin and Echocardiography}

7 hat's what started this whole journey. Before the end of the 1970s, most neonates with critical congenital heart disease (CHD) did not survive if their pulmonary or systemic blood flow was dependent on a patent ductus arteriosus. Even in the rare neonate who was lucky enough to have spontaneous patency of the ductus, making a complete diagnosis to plan cardiac surgery required catheterization; 30 years ago cardiac catheterization was associated with significant morbidity, especially in a fragile neonate. It's no wonder surgical mortality was so high in those days. Even though the technical aspects of cardiac surgery could be applied to small babies, the status of the infant entering the operating room was tenuous, and the infant not infrequently had an incomplete diagnosis.

Enter bedside noninvasive diagnostic capabilities and the availability of medical support to stabilize the infant. Mechanical ventilation was being applied to smaller and smaller infants, hemodynamic monitoring was improving, and the new subspecialty of cardiac intensive care allowed for increasingly stable babies to survive palliative and reparative procedures. Improvements in surgical technique and cardiopulmonary bypass followed soon thereafter. Intraoperative echocardiography increased the likelihood of leaving the operating room with a better understanding of the physiology of the neonate and status of the repair.

For those of us in the practice of pediatric cardiology, this was an exciting time indeed. Survival, even for infants with the most complex lesions, was now expected. Cardiologists and intensivists painted a very different prognosis for families than we had even 10 years earlier. However, with these successes came new realizations. As we began to observe these outpatients in larger numbers, we recognized that there was an unexpectedly high prevalence of psychosocial, neurologic, developmental, and psychiatric disabilities in the survivors as they entered and proceeded through formal education. Gross and fine motor delays, learning disabilities, inattention, hyperactivity, internalizing and externalizing behaviors, and speech and language difficulties have all been reported with disturbingly high frequency, approaching $40 \%$ to $50 \%$ in some subgroups. ${ }^{1}$ The neurodevelopmental burden of disease is, for many children and their families, much more significant than the daily impact of their CHD. ${ }^{\mathrm{E} 1}$ (See E-References on line.) Many families of teenagers with complex CHD and significant learning or behavioral problems openly ask me why they were not informed of these potential problems when their children were born. It is of little solace that I tell them that when their child was born in the late 1980s and early 1990s, there were simply not enough school-age survivors to know the true impact of CHD and its management on longer term quality of life. Fortunately, children and their parents began to participate in longitudinal clinical research efforts so that we might gain improved understanding of the types and frequency of neurodevelopmental dysfunction and begin to understand the mechanism(s) of injury. 


\section{Partnership and Equipoise}

In this issue, the investigators at Children's Hospital Boston present another in a series of important investigations aimed at improving our understanding of the mechanisms of central nervous system injury in the operating room and proposing changes in management to improve the longer term outlook for our current patients. ${ }^{2,3}$ At the outset, Newburger (cardiology), Jonas (cardiac surgery), Bellinger (psychology), Wypij (biostatistics), and their many colleagues understood the value in the multidisciplinary design of clinical investigations. I was fortunate as a junior physician to be mentored by that group. Partnership extended from study design through implementation in the intensive care unit, getting "buy-in" from colleagues in medicine, surgery, anesthesia, and nursing, and most importantly, the families of our patients. We believed then, as now, that clinical investigation of long-term outcomes was a moral imperative and all needed to participate as partners in the challenge, from many disciplines both inside and outside of pediatric cardiology and surgery. Whereas getting many investigators (frequently seasoned investigators with long research track records) to agree on the important questions, the patient population to study, the financial realities of clinical studies, and even the order of authors on manuscripts was "challenging," equipoise was perhaps the hardest of all hurdles to overcome. In our field, it is natural to "know" (or be expected to know) the "correct" approach to a procedure, the "right" diagnosis: the "truth." How can a surgeon with so much on the line be expected to "flip a coin" to decide what bypass strategy to use, what surgical technique to use? How could we convince parents of critically ill neonates to sign a consent form allowing us to be — by design-random in our decision making? ${ }^{\mathrm{E} 2}$ How could we convince our colleagues who referred patients to us to allow their patients to enter a clinical trial? These were difficult problems in theory, but the leadership in the cardiovascular program provided by Dr Aldo Castañeda and Dr James Lock continued to foster an approach that this was clearly the best way in which the field could move forward and improve results for the next generation. Multidisciplinary study groups were encouraged and indeed became the model of clinical investigation of long-term outcomes for our patients.

The knowledge gained from the randomized trials in Boston have included investigations of the use and duration of deep hypothermic circulatory arrest, ${ }^{4,5, \text { E6-E11 }} \mathrm{pH}$ management, ${ }^{6, \mathrm{E} 12}$ and, in the current issue, follow-up and further analysis on the effect of hematocrit management during cardiopulmonary bypass., ${ }^{2,3, E 13}$ Much has been learned from these trials that has affected our current approaches to cardiopulmonary bypass and perioperative management. In addition to the lessons learned from the important trials in Boston, a subtle "culture change" has occurred in our field. New changes in technique are more frequently subjected to critical review and implemented as clinical trials rather than immediately adopted as "better" or "proven." Practice change by anecdote, seniority, or by comparing new techniques to historical controls is no longer a viable, acceptable strategy. ${ }^{\text {E14 }}$ Additional randomized clinical trials of intraoperative and perioperative management have recently been published ${ }^{\mathrm{E} 15, \mathrm{E} 16}$ and are currently underway, including multicenter trials supported by the Pediatric Heart Network (www.pediatricheartnetwork.org/ currentstudies.asp, accessed 2007).

\section{Prospective and Evidence-based Studies}

In addition to the randomized studies in Boston, a number of cohorts are currently being evaluated prospectively with protocol-driven follow-up to learn more about the impact of factors outside the operating room that affect long-term neurodevelopmental outcomes. Large cohorts of patients with heterogeneous CHD are currently being prospectively followed up at The Children's Hospital of Philadelphia ${ }^{7, E 17-E 20}$ as well as at Montreal Children's Hospital ${ }^{8, \mathrm{E} 21-\mathrm{E} 28}$ and the University Hospital in Aachen, Germany. ${ }^{9, E 29-35}$ Additional prospective and cross-sectional reports are increasingly prevalent in the literature. ${ }^{\mathrm{E} 36-\mathrm{E} 42} \mathrm{All}$ of the current evidence points to the fact that modifications of technique in the operating room, although important, contribute but a small fraction to the variability of longer term outcomes in the decades that follow neonatal cardiac intervention. Instead, nonmodifiable factors such as gestational age, birth weight, genetic syndromes and polymorphisms, maternal education, and socioeconomic status have been consistently and significantly implicated as major contributors to long-term outcome. ${ }^{\text {E43 }}$ Therefore, prospective studies must continue to define the impact of modifiable risk factors: how we operate, when we operate, and importantly, how we manage the patient in the intensive care unit. During a typical hospitalization for neonatal heart surgery, only a small fraction of the total length of stay is spent in the operating room, where a disproportionate (though very important) amount of clinical investigation has taken place. Resources and clinical investigations need also to study management patterns in the intensive care unit. Changes in management must be accompanied by investigation into their short- and long-term impact to establish an evidence base to design future prospective follow-up studies and randomized treatment clinical trials. Just a few examples of practice patterns that have not been adequately studied for their impact on longer term neurodevelopment include timing of surgery in critical lesions, "routine" delayed sternal closure, ${ }^{\text {E4-E47 }}$ management of hyperglycemia, ${ }^{\text {E48,E49 }}$ temperature control, ${ }^{\text {E50-E52 }}$ nutrition, ${ }^{\text {E53 }}$ and the impact of mechanical ventilation/hyperventilation ${ }^{\mathrm{E} 54}$ on longer term outcomes. Some are likely to be important, and it is time to study factors in the intensive care unit as 
rigorously as we have studied factors in the operating room. We need to be more critical of our current strategies as being "right." We should model our trials and clinical investigations on the approach taken by the Boston group for nearly 20 years, to have equipoise regarding our current strategies, study them rigorously, in a multidisciplinary, multicenter, and importantly, long-term fashion. We may find that our practices and established techniques may be all wrong.

\section{References}

1. Wernovsky G. Current insights regarding neurological and developmental abnormalities in children and young adults with complex congenital cardiac disease. Cardiol Young. 2006;16(Suppl 1):92-104.

2. Newburger JW, Jonas RA, Soul J, Kussman BD, Bellinger DC, Laussen PC, et al. Randomized trial of hematocrit $25 \%$ versus 35\% during hypothermic cardiopulmonary bypass in infant heart surgery. $J$ Thorac Cardiovasc Surg. 2008;135:347-54.

3. Wypij D, Jonas RA, Bellinger DC, del Nido PJ, Mayer JE Jr, Bacha EA, et al. The effect of hematocrit during hypothermic cardiopulmonary bypass in infant heart surgery: results from the combined Boston hematocrit trials. $J$ Thorac Cardiovasc Surg. 2008;135:355-60.

4. Wypij D, Newburger JW, Rappaport LA, duPlessis AJ, Jonas RA, Wernovsky G, et al. The effect of duration of deep hypothermic circulatory arrest in infant heart surgery on late neurodevelopment: the Boston Circulatory Arrest Trial. J Thorac Cardiovasc Surg. 2003;126: 1397-403.

5. Bellinger DC, Wypij D, duPlessis AJ, Rappaport LA, Jonas RA, Wernovsky G, et al. Neurodevelopmental status at eight years in children with dextro-transposition of the great arteries: the Boston Circulatory Arrest Trial. J Thorac Cardiovasc Surg. 2003;126:1385-96.

6. du Plessis AJ, Jonas RA, Wypij D, Hickey PR, Riviello J, Wessel DL, et al. Perioperative effects of alpha-stat versus $\mathrm{pH}$-stat strategies for deep hypothermic cardiopulmonary bypass in infants. $J$ Thorac Cardiovasc Surg. 1997;114:991-1000.

7. Gaynor JW, Gerdes M, Zackai EH, Bernbaum J, Wernovsky G, Clancy RR, et al. Apolipoprotein E genotype and neurodevelopmental sequelae of infant cardiac surgery. J Thorac Cardiovasc Surg. 2003;126:1736-45.

8. Majnemer A, Limperopoulos C, Shevell M, Rohlicek C, Rosenblatt B, Tchervenkov C. Health and well-being of children with congenita cardiac malformations, and their families, following open-heart surgery. Cardiol Young. 2006;16:157-64.

9. Hovels-Gurich HH, Konrad K, Skorzenski D, Herpertz-Dahlmann B Messmer BJ, Seghaye MC. Attentional dysfunction in children after corrective cardiac surgery in infancy. Ann Thorac Surg. 2007;83:1425-30. 


\section{E-References}

E1. Wray J, Maynard L. The needs of families of children with heart disease. J Dev Behav Pediatr. 2006;27:11-7.

E2. Hoehn KS, Wernovsky G, Rychik J, Gaynor JW, Spray TL, Feudtner $\mathrm{C}$, et al. What factors are important to parents making decisions about neonatal research? Arch Dis Child Fetal Neonatal Ed. 2005; 90:F267-9.

E3. McGrath E, Wypij D, Rappaport LA, Newburger JW, Bellinger DC. Prediction of IQ and achievement at age 8 years from neurodevelopmental status at age 1 year in children with D-transposition of the great arteries. Pediatrics. 2004;114:e572-6.

E4. Bartlett JM, Wypij D, Bellinger DC, Rappaport LA, Heffner LJ, Jonas RA, et al. Effect of prenatal diagnosis on outcomes in D-transposition of the great arteries. Pediatrics. 2004;113:e335-40.

E5. Newburger JW, Wypij D, Bellinger DC, du Plessis AJ, Kuban $\mathrm{KC}$, Rappaport LA, et al. Length of stay after infant heart surgery is related to cognitive outcome at age 8 years. J Pediatr. 2003; 143:67-73.

E6. Dunbar-Masterson C, Wypij D, Bellinger DC, Rappaport LA, Baker AL, Jonas RA, et al. General health status of children with Dtransposition of the great arteries after the arterial switch operation. Circulation. 2001;104(12 Suppl 1):I138-42.

E7. Bellinger DC, Wypij D, Kuban KC, Rappaport LA, Hickey PR, Wernovsky G, et al. Developmental and neurological status of children at 4 years of age after heart surgery with hypothermic circulatory arrest or low-flow cardiopulmonary bypass. Circulation. 1999; 100:526-32.

E8. Rappaport LA, Wypij D, Bellinger DC, Helmers SL, Holmes GL, Barnes PD, et al. Relation of seizures after cardiac surgery in early infancy to neurodevelopmental outcome. Boston Circulatory Arrest Study Group. Circulation. 1998;97:773-9.

E9. Bellinger DC, Rappaport LA, Wypij D, Wernovsky G, Newburger JW. Patterns of developmental dysfunction after surgery during infancy to correct transposition of the great arteries. J Dev Behav Pediatr. 1997; 18:75-83.

E10. Bellinger DC, Jonas RA, Rappaport LA, Wypij D, Wernovsky G, Kuban KC, et al. Developmental and neurologic status of children after heart surgery with hypothermic circulatory arrest or low-flow cardiopulmonary bypass. N Engl J Med. 1995;332:549-55.

E11. Bellinger DC, Wernovsky G, Rappaport LA, Mayer JE Jr, Castaneda AR, Farrell DM, et al. Cognitive development of children following early repair of transposition of the great arteries using deep hypothermic circulatory arrest. Pediatrics. 1991;87:701-7.

E12. Jonas RA, Bellinger DC, Rappaport LA, Wernovsky G, Hickey PR, Farrell DM, et al. Relation of $\mathrm{pH}$ strategy and developmental outcome after hypothermic circulatory arrest. J Thorac Cardiovasc Surg. 1993;106:362-8.

E13. Jonas RA, Wypij D, Roth SJ, Bellinger DC, Visconti KJ, du Plessis AJ, et al. The influence of hemodilution on outcome after hypothermic cardiopulmonary bypass: results of a randomized trial in infants. J Thorac Cardiovasc Surg. 2003;126:1765-74.

E14. Tabbutt S, Dominguez TE, Ravishankar C, Marino BS, Gruber PJ, Wernovsky G, et al. Outcomes after the stage I reconstruction comparing the right ventricular to pulmonary artery conduit with the modified Blalock Taussig shunt. Ann Thorac Surg. 2005;80: 1582-90.

E15. Hoffman TM, Wernovsky G, Atz AM, Kulik TJ, Nelson DP, Chang AC, et al. Efficacy and safety of milrinone in preventing low cardiac output syndrome in infants and children after corrective surgery for congenital heart disease. Circulation. 2003;107:996-1002.

E16. Mackie AS, Booth KL, Newburger JW, Gauvreau K, Huang SA, Laussen PC, et al. A randomized, double-blind, placebo-controlled pilot trial of triiodothyronine in neonatal heart surgery. $J$ Thorac Cardiovasc Surg. 2005;130:810-6.

E17. Clancy RR, McGaurn SA, Goin JE, Hirtz DG, Norwood WI, Gaynor $\mathrm{JW}$, et al. Allopurinol neurocardiac protection trial in infants undergoing heart surgery using deep hypothermic circulatory arrest. $\mathrm{Pe}$ diatrics. 2001;108:61-70.

E18. Kaltman JR, Jarvik GP, Bernbaum J, Wernovsky G, Gerdes M, Zackai E, et al. Neurodevelopmental outcome after early repair of a ventricular septal defect with or without aortic arch obstruction. J Thorac Cardiovasc Surg. 2006;131:792-8.

E19. Kirshbom PM, Flynn TB, Clancy RR, Ittenbach RF, Hartman DM, Paridon SM, et al. Late neurodevelopmental outcome after repair of total anomalous pulmonary venous connection. J Thorac Cardiovasc Surg. 2005;129:1091-7.

E20. Schultz AH, Jarvik GP, Wernovsky G, Bernbaum J, Clancy RR, D'Agostino JA, et al. Effect of congenital heart disease on neurodevelopmental outcomes within multiple-gestation births. J Thorac Cardiovasc Surg. 2005;130:1511-6.

E21. Majnemer A, Limperopoulos C, Shevell M, Rosenblatt B, Rohlicek C, Tchervenkov C. Long-term neuromotor outcome at school entry of infants with congenital heart defects requiring open-heart surgery. J Pediatr. 2006;148:72-7.

E22. Limperopoulos C, Majnemer A, Rosenblatt B, Shevell MI, Rohlicek C, Tchervenkov C. Agreement between the neonatal neurological examination and a standardized assessment of neurobehavioural performance in a group of high-risk newborns. Pediatr Rehabil. 1997;1:9-14.

E23. Limperopoulos C, Majnemer A, Shevell MI, Rosenblatt B, Rohlicek C, Tchervenkov C. Neurologic status of newborns with congenital heart defects before open heart surgery. Pediatrics. 1999;103:402-8.

E24. Limperopoulos C, Majnemer A, Shevell MI, Rosenblatt B, Rohlicek C, Tchervenkov C. Neurodevelopmental status of newborns and infants with congenital heart defects before and after open heart surgery. J Pediatr. 2000;137:638-45.

E25. Limperopoulos C, Majnemer A, Rosenblatt B, Shevell MI, Rohlicek C, Tchervenkov C, et al. Association between electroencephalographic findings and neurologic status in infants with congenital heart defects. J Child Neurol. 2001;16:471-6.

E26. Limperopoulos C, Majnemer A, Shevell MI, Rosenblatt B, Rohlicek $\mathrm{C}$, Tchervenkov $\mathrm{C}$, et al. Functional limitations in young children with congenital heart defects after cardiac surgery. Pediatrics. 2001; 108:1325-31.

E27. Limperopoulos C, Majnemer A, Shevell MI, Rohlicek C, Rosenblatt B, Tchervenkov C, et al. Predictors of developmental disabilities after open heart surgery in young children with congenital heart defects. J Pediatr. 2002;141:51-8.

E28. Majnemer A, Limperopoulos C. Developmental progress of children with congenital heart defects requiring open heart surgery. Semin Pediatr Neurol. 1999;6:12-9.

E29. Hovels-Gurich HH, Konrad K, Skorzenski D, Nacken C, Minkenberg $\mathrm{R}$, Messmer BJ, et al. Long-term neurodevelopmental outcome and exercise capacity after corrective surgery for tetralogy of Fallot or ventricular septal defect in infancy. Ann Thorac Surg. 2006;81:958-66.

E30. Hovels-Gurich HH, Seghaye MC, Ma Q, Miskova M, Minkenberg $\mathrm{R}$, Messmer BJ, et al. Long-term results of cardiac and general health status in children after neonatal arterial switch operation. Ann Thorac Surg. 2003;75:935-43.

E31. Hovels-Gurich HH, Konrad K, Wiesner M, Minkenberg R, HerpertzDahlmann B, Messmer BJ, et al. Long term behavioural outcome after neonatal arterial switch operation for transposition of the great arteries. Arch Dis Child. 2002;87:506-10.

E32. Hovels-Gurich HH, Seghaye MC, Schnitker R, Wiesner M, Huber W, Minkenberg R, et al. Long-term neurodevelopmental outcomes in school-aged children after neonatal arterial switch operation. J Thorac Cardiovasc Surg. 2002;124:448-58.

E33. Hovels-Gurich HH, Seghaye MC, Sigler M, Kotlarek F, Bartl A, Neuser J, et al. Neurodevelopmental outcome related to cerebral risk factors in children after neonatal arterial switch operation. Ann Thorac Surg. 2001;71:881-8.

E34. Hovels-Gurich HH, Seghaye MC, Dabritz S, Messmer BJ, von Bernuth G. Cardiological and general health status in preschool- and school-age children after neonatal arterial switch operation. Eur J Cardiothorac Surg. 1997;12:593-601.

E35. Hovels-Gurich HH, Seghaye MC, Dabritz S, Messmer BJ, von Bernuth G. Cognitive and motor development in preschool and school-aged children after neonatal arterial switch operation. J Thorac Cardiovasc Surg. 1997;114:578-85. 
E36. Forbess JM, Visconti KJ, Bellinger DC, Jonas RA. Neurodevelopmental outcomes in children after the Fontan operation. Circulation. 2001;104(12 Suppl 1):I127-32.

E37. Forbess JM, Visconti KJ, Hancock-Friesen C, Howe RC, Bellinger DC, Jonas RA. Neurodevelopmental outcome after congenital heart surgery: results from an institutional registry. Circulation. 2002; 106(12 Suppl 1):I95-102.

E38. Forbess JM, Visconti KJ, Bellinger DC, Howe RJ, Jonas RA. Neurodevelopmental outcomes after biventricular repair of congenital heart defects. J Thorac Cardiovasc Surg. 2002;123:631-9.

E39. Wernovsky G, Stiles KM, Gauvreau K, Gentles TL, duPlessis AJ, Bellinger DC, et al. Cognitive development after the Fontan operation. Circulation. 2000;102:883-9.

E40. Cheung PY, Chui N, Joffe AR, Rebeyka IM, Robertson CMT. Postoperative lactate concentrations predict the outcome of infants aged 6 weeks or less after intracardiac surgery: a cohort follow-up to 18 months. J Thorac Cardiovasc Surg. 2005;130:837-43.

E41. Dittrich H, Buhrer C, Grimmer I, Dittrich S, Abdul-Khaliq H, Lange PE. Neurodevelopment at 1 year of age in infants with congenital heart disease. Heart. 2003;89:436-41.

E42. Kern JH, Hinton VJ, Nereo NE, Hayes CJ, Gersony WM. Early developmental outcome after the Norwood procedure for hypoplastic left heart syndrome. Pediatrics. 1998;102:1148-52.

E43. Gaynor JW, Wernovsky G, Jarvik GP, Bernbaum J, Gerdes M, Zackai E, et al. Patient characteristics are important determinants of neurodevelopmental outcome at one year of age after neonatal and infant cardiac surgery. J Thorac Cardiovasc Surg. 2007;133:1344-53.

E44. Owens WA, Vitale N, Hasan A, Hamilton JRL. A policy of elective delayed sternal closure does not improve the outcome after arterial switch. Ann Thorac Surg. 2001;71:1553-5.

E45. Riphagen S, McDougall M, Tibby SM, Alphonso N, Anderson D, Austin C, et al. "Early" delayed sternal closure following pediatric cardiac surgery. Ann Thorac Surg. 2005;80:678-85.
E46. Samir K, Riberi A, Ghez O, Ali M, Metras D, Kreitmann B. Delayed sternal closure: a life-saving measure in neonatal open heart surgery; could it be predictable? Eur J Cardiothorac Surg. 2002;21:787-93.

E47. Tabbutt S, Duncan BW, McLaughlin D, Wessel DL, Jonas RA, Laussen PC. Delayed sternal closure after cardiac operations in a pediatric population. J Thorac Cardiovasc Surg. 1997;113:886-93.

E48. de Ferranti S, Gauvreau K, Hickey PR, Jonas RA, Wypij D, du Plessis A. Intraoperative hyperglycemia during infant cardiac surgery is not associated with adverse neurodevelopmental outcomes at 1, 4, and 8 years. Anesthesiology. 2004;100:1345-52.

E49. Yates AR, Dyke PC, Taeed R, Hoffman TM, Hayes J, Feltes TF, et al. Hyperglycemia is a marker for poor outcome in the postoperative pediatric cardiac patient. Pediatr Crit Care Med. 2006;7:351-5.

E50. Cottrell SM, Morris KP, Davies P, Bellinger DC, Jonas RA, Newburger JW. Early postoperative body temperature and developmental outcome after open heart surgery in infants. Ann Thorac Surg. 2004;77:66-71

E51. Sakamoto T, Zurakowski D, Duebener LF, Lidov HG, Holmes GL, Hurley RJ, et al. Interaction of temperature with hematocrit level and $\mathrm{pH}$ determines safe duration of hypothermic circulatory arrest. J Thorac Cardiovasc Surg. 2004;128:220-32.

E52. Tabbutt S, Ittenbach RF, Nicolson SC, Burnham N, Hittle S, Spray $\mathrm{TL}$, et al. Intracardiac temperature monitoring in infants after cardiac surgery. J Thorac Cardiovasc Surg. 2006;131:614-20.

E53. Kelleher DK, Laussen P, Teixeira-Pinto A, Duggan C. Growth and correlates of nutritional status among infants with hypoplastic left heart syndrome (HLHS) after stage 1 Norwood procedure. Nutrition. 2006;223:237-44.

E54. Bassan H, Gauvreau K, Newburger JW, Tsuji M, Limperopoulos C, Soul JS, et al. Identification of pressure passive cerebral perfusion and its mediators after infant cardiac surgery. Pediatr Res. 2005;57: $35-41$. 